\title{
UJI BORAKS DAN FORMALIN PADA JAJANAN DISEKITAR UNIVERSITAS YUDHARTA PASURUAN
}

\author{
Test Boraks and Formalin on The Ride Distributed University Yudharta Pasuruan
}

\author{
Deny Utomoa ${ }^{1)}$ dan Siti Kholifah ${ }^{1}{ }^{*}$ \\ ${ }^{1}$ Program Studi ITP, Fakultas Pertanian, Universitas Yudharta Pasuruan \\ *Email : denyut369@gmail.com
}

\begin{abstract}
Food safety is a matter that must be considered because it can affect health, both for children and adults. According to data from the Food and Drug Supervisory Agency (BPOM), during the year 2012, the incidence of food poisoning poisoning occupied the highest position, ie $66.7 \%$. One of the causes of food poisoning is the presence of food additives such as formalin, borax, and textile dye in food. Around the University of Yudharta Pasuruan there are so many sellers of snacks, such as; cilok, wet noodles, meatballs, snack foods, and drinks. This study aims to find snacks containing borax and formalin and to know snacks that are safe and insecure for children. The sampling was done by simple random technique with the assumption of the samples that many children interested in and suspected to contain borax and formalin, so that the samples obtained as much as 9 snack samples obtained from 7 sellers snacks. Then the samples were coded $A, B, C, D$, $E, F, G, H$ and $I$. In this study the test of borax and formalin was carried out qualitatively using a borax test kit and formalin kit test. From the results of the study showed that from 9 samples of snack foods tested, 2 positive samples containing borax are samples $H$ and I. As for formalin test, none of the snack samples containing formalin. So it can be concluded that safe snacks consumed are samples $A, B, C, D, E, F$ and $G$. The samples are declared negatively containing borax and formalin.
\end{abstract}

Keywords: Food safety, food snacks, food preservative, borax, formalin.

\begin{abstract}
ABSTRAK
Keamanan pangan merupakan suatu hal yang harus diperhatikan karena dapat berdampak pada kesehatan, baik bagi anak-anak maupun orang dewasa. Menurut data dari Badan Pengawas Obat dan Makanan (BPOM), sepanjang tahun 2012, insiden keracunan akibat mengonsumsi makanan menduduki posisi paling tinggi, yaitu $66,7 \%$. Salah satu penyebab keracunan makanan adalah adanya kandungan bahan tambahan pangan seperti formalin, boraks, dan pewarna tekstil dalam makanan. Disekitar Universitas Yudharta Pasuruan banyak sekali penjual jajanan, seperti ; cilok, mie basah, bakso, kudapan makanan ringan, dan aneka minuman. Penelitian ini bertujuan untuk mengetahui jajanan yang mengandung boraks dan formalin dan untuk mengetahui jajanan yang aman dan tidak aman bagi anak-anak. Pengambilan sampel dilakukan dengan teknik simple random dengan asumsi sampel yang banyak diminati anak-anak dan dicurigai mengandung boraks dan formalin, sehingga didapatkan sampel sebanyak 9 sampel jajanan yang didapatkan dari 7 penjual jajanan. Kemudian sampel diberi kode A, B, C, D, E, F, G, H dan I. Dalam penelitian ini uji boraks dan formalin dilakukan secara kualitatif yaitu menggunakan test kit boraks dan tes kit formalin. Dari hasil penelitian menunjukkan bahwa dari 9 sampel makanan jajanan yang diuji, 2 sampel positif mengandung boraks yaitu sampel $\mathrm{H}$ dan I. Sedangkan untuk uji formalin, tidak satu pun sampel jajanan yang mengandung formalin. Sehingga bisa disimpulkan bahwa jajanan yang
\end{abstract}


aman dikonsumsi adalah sampel A, B, C, D, E, F dan G. Sampe-sampel tersebut dinyatakan negatif mengandung boraks dan formalin.

Kata kunci : Keamanan pangan, makanan jajanan, pengawet makanan, boraks, formalin.

\section{PENDAHULUAN}

Keamanan pangan merupakan suatu hal yang harus diperhatikan karena dapat berdampak pada kesehatan, baik bagi anakanak maupun orang dewasa. Menurut data dari Badan Pengawas Obat dan Makanan (BPOM), sepanjang tahun 2012, insiden keracunan akibat mengonsumsi makanan menduduki posisi paling tinggi, yaitu $66,7 \%$, dibandingkan dengan keracunan akibat penyebab lain, misalnya obat, kosmetika, dan lain-lain. Salah satu penyebab keracunan makanan adalah adanya kandungan bahan tambahan pangan seperti formalin, boraks, dan pewarna tekstil dalam makanan (Paratmantya dan Aprilia, 2016).

Disekitar Universitas Yudharta Pasuruan banyak sekali penjual jajanan, seperti ; cilok, mie basah, bakso, kudapan makanan ringan, dan aneka minuman. Penelitian ini bertujuan untuk mengetahui jajanan yang mengandung boraks dan formalin dan untuk mengetahui jajanan yang aman dan tidak aman bagi anak-anak.

Boraks atau biasa disebut asam borat, memiliki nama lain, sodium tetraborate biasa digunakan untuk antiseptik dan zat pembersih selain itu digunakan juga sebagai bahan baku pembuatan detergen, pengawet kayu, antiseptik kayu, pengontrol kecoak (hama), pembasmi semut dan lainnya (Adinugroho, 2013).

Formalin adalah senyawa formaldehid dalam air dengan konsentrasi rata-rata $37 \%$ dan methanol $15 \%$ dan sisanya adalah air. Penggunaan formalin antara lain sebagai pembunuh kuman sehingga digunakan sebagai pembersih lantai, gudang, pakaian dan kapal, pembasmi lalat dan serangga lainnya, bahan pembuat sutra buatan, zat pewarna, cermin kaca dan bahan peledak. Dalam dunia fotografi biasanya digunakan untuk pengeras lapisan gelatin dan kertas, bahan pembentuk pupuk berupa urea, bahan pembuatan produk parfum, bahan pengawet produk kosmetik dan pengeras kuku, pencegah korosi untuk sumur minyak, bahan untuk isolasi busa, bahan perekat untuk produk kayu lapis (playwood), dalam konsentrasi yang sangat kecil $(<1 \%)$ digunakan sebagai pengawet, pembersih rumah tangga, cairan pencuci piring, pelembut, perawat sepatu, shampo mobil, lilin dan karpet (Astawan, 2006).

Meskipun bukan pengawet makanan, boraks dan formalin sering pula digunakan sebagai pengawet makanan. Boraks dan formalin sering disalahgunakan untuk mengawetkan berbagai makanan seperti bakso, mie basah, pisang molen, siomay, lontong, ketupat, pangsit, dsb. Selain bertujuan untuk mengawetkan, boraks dan formalin juga dapat membuat tekstur makanan menjadi lebih kenyal dan memperbaiki penampilan makanan, utuh, tidak rusak, menekan biaya produksi, praktis dan efektif mengawetkan makanan.

Menurut Peraturan Menteri Kesehatan RI No.722 tahun 1988, boraks dan formalin digolongkan sebagai bahan tambahan pangan yang tidak izinkan di Indonesia. Penyebab boraks dan formalin dilarang penggunaanya adalah karena boraks dan formalin banyak menimbulkan penyakit bagi kesehatan.

Formalin akan menyebabkan iritasi dan rasa terbakar pada mukosa kavum nasi, mulut dan saluran nafas bagian atas jika masuk secara inhalasi. Pada konsentrasi lebih tinggi mampu mencapai bronkiolus dan alveoli lalu menginduksi edema paru dan pneumonia. Sedangkan bila tertelan dalam konsentrasi tinggi menimbulkan gejala akut berupa iritasi di mulut, kerongkongan, ulkus di saluran pencernaan, nyeri dada dan perut, mual, muntah, diare, perdarahan gastrointestinal, asidosis metabolik, gagal ginjal bahkan kematian (Hearn, 2007).

Sedangkan boraks dapat menyebabkan gangguan otak, hati, dan ginjal. Dalam jumlah banyak boraks menyebabkan demam, anuria, koma, kerusakan sistem saraf pusat, sianosis, 
kerusakan ginjal, anemia, muntah, diare, pingsan, bahkan kematian (Widyaningsih dan Murtini, 2006).

\section{METODE PENELITIAN}

Populasi penelitian ini adalah penjual jajanan disekitar Universitas Yudharta Pasuruan. Pengambilan sampel dilakukan dengan teknik simple random sampling dengan asumsi sampel yang banyak diminati anak-anak dan dicurigai mengandung boraks dan formalin, sehingga didapatkan sampel sebanyak 9 sampel jajanan yang didapatkan dari 7 penjual jajanan. Kemudian sampel diberi kode A, B, C, D, E, F, G, H dan I.

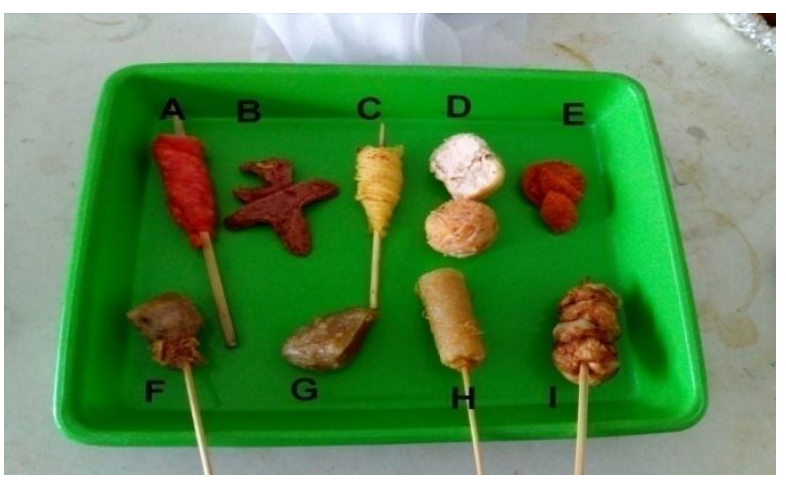

Gambar 1. Sampel jajanan

Uji boraks dan formalin dilakukan secara kualitatif pada sampel jajanan dengan menggunakan test kit boraks dan test kit formalin.

Bahan-bahan yang digunakan dalam penelitian ini adalah sampel jajanan yang diambil dari beberapa penjual jajanan yang ada disekitar Universitas Yudharta Pasuruan, test kit boraks dan formalin (chemkit) dan aquades.

Alat-alat yang digunakan dalam peneltian ini adalah kertas label, telenan, pisau, tabung reaksi $10 \mathrm{ml}$, beaker glass $50 \mathrm{ml}$ dan $500 \mathrm{ml}$, spatula, pipet dan spidol.

\section{Pengujian Boraks}

1. Sampel dicincang kecil-kecil.

2. Masukkan sampel sebanyak 1 gram kedalam tabung reaksi $10 \mathrm{ml}$.
3. Tambahkan aquades sebanyak 2-3 ml.

4. Aduk sampel dengan menggunakan spatula hingga tercampur rata.

5. Teteskan reagen boraks sebanyak 20 tetes. Kemudian celupkan paper test kit (kertas lakmus) dan tempel paper test kit disamping tabung reaksi, tunggu hingga 10 menit dibawah terik matahari. Dengan tujuan agar reagen boraks bereaksi dengan maksimal.

6. Setelah 10 menit, lihat perubahan warna pada paper test kit. Apabila paper test kit berubah warna menjadi merah bata atau merah kecoklatan, maka sampel dinyatakan positif mengandung boraks. Dan jika tidak terjadi perubahan warna, maka sampel dinyatakan negatif mengandung boraks.

\section{Pengujian Formalin}

1. Sampel dicincang kecil-kecil.

2. Masukkan sampel sebanyak 10 gram kedalam beaker glass $50 \mathrm{ml}$.

3. Rendam sampel dengan aquades.

4. Ambil larutan sampel sebanyak $1 \mathrm{ml}$ kedalam tabung reaksi $10 \mathrm{ml}$.

5. Teteskan reagen 1 formalin sebanyak 5 tetes, setelah itu tambahkan reagen 2 yang beruapa serbuk sebanyak 1 sendok kecil (bagian alat di test kit). Kemudian tunggu selama 10 menit untuk mengetahui perubahan warna yang akan terjadi pada larutan sampel. Apabila larutan berubah warna menjadi pink keunguan, maka sampel dinyatakan positif mengandung formalin. Dan jika tidak terjadi perubahan warna, maka sampel dinyatakan negatif mengandung formalin.

Teknik pengumpulan data dalam penelitian ini ada 2 yaitu teknik wawancara dan uji laboratorium. Wawancara yaitu mendapatkan informasi dengan cara bertanya langsung kepada responden (penjual jajanan) yang meliputi jenis kelamin (laki-laki atau perempuan), usia penjual (17-25 tahun, 26-35 tahun, 36-45 tahun dan 46-55 tahun), tingkat 
pendidikan (tidak tamat SD, tamat SD, tamat SMP, tamat SMA dan tamat perguruan tinggi), masa kerja penjual makanan jajanan ( $\leq 1$ tahun, 1-5 tahun, 6-10 tahun dan $\geq 10$ tahun) dan kepemilikan usaha (sendiri atau bukan milik sendiri). Uji laboratorium pada penelitian ini digunakan untuk mengetahui apakah jajanan disekitar Universitas Yudharta Pasuruan mengandung boraks dan formalin atau tidak.

\section{HASIL DAN PEMBAHASAN}

Populasi dalam penelitian ini adalah penjual jajanan yang berada disekitar Universitas Yudharta Pasuruan. Dari hasil wawancara, didapatkan data sebagai pada Tabel 1.

Berdasarkan Tabel 1 menunjukkan bahwa paling banyak penjual berjenis kelamin laki-laki dengan jumlah 5 penjual $(71,43 \%)$ dan yang berjenis kelamin perempuan berjumlah 2 penjual $(28,57 \%)$. Berdasarkan dari segi usia penjual yang paling banyak adalah berusia 26-35 tahun dengan jumlah 4 penjual $(57,14 \%)$, diikuti dengan usia $36-45$ tahun dengan 2 penjual $(28,57 \%)$ dan yang paling sedikit adalah usia 46-55 tahun yaitu 1 penjual $(14,29 \%)$. Untuk tingkat pendidikan paling banyak adalah tamatan SD dengan 3 penjual $(42,86 \%)$ dan tingkat pendidikan tamatan SMP dan SMA masing-masing sebanyak 2 penjual $(28,57 \%)$. Kemudian masa kerja penjual dalam penelitian ini paling banyak adalah masa kerja 6-10 tahun dengan 3 penjual $(42,86 \%)$, diikuti masa kerja $\leq 1$ tahun dan 1-5 tahun dengan masing-masing berjumlah 2 penjual $(28,57 \%)$ dan penjual dengan masa kerja lebih dari 10 tahun belum ada. Diketahui juga berdasarkan status kepemilikan usaha, rata-rata adalah usaha milik sendiri yaitu 7 penjual (100\%).

Tabel 1. Karakteristik penjual jajanan

\begin{tabular}{|c|c|c|c|}
\hline No. & Karakteristik & $\mathrm{N}$ & $\%$ \\
\hline 1. & $\begin{array}{l}\text { Jenis kelamin } \\
\text { o Laki-laki } \\
\text { o Perempuan }\end{array}$ & $\begin{array}{l}5 \\
2\end{array}$ & $\begin{array}{l}71,43 \\
28,57\end{array}$ \\
\hline 2. & $\begin{array}{l}\text { Usia (tahun) } \\
\begin{array}{ll}\circ & 17-25 \\
\circ & 26-35 \\
\circ & 36-45 \\
\circ & 46-55\end{array}\end{array}$ & $\begin{array}{l}- \\
4 \\
2 \\
1\end{array}$ & $\begin{array}{c}- \\
57,14 \\
28,57 \\
14,29\end{array}$ \\
\hline 3. & $\begin{array}{l}\text { Tingkat pendidikan } \\
\text { O Tidak tamat SD } \\
\circ \text { Tamat SD } \\
\circ \text { Tamat SMP } \\
\circ \text { Tamat SMA } \\
\circ \\
\text { Tamat PT }\end{array}$ & $\begin{array}{l}- \\
3 \\
2 \\
2 \\
-\end{array}$ & $\begin{array}{c}- \\
42,86 \\
28,57 \\
28,57 \\
-\end{array}$ \\
\hline 4. & $\begin{array}{l}\text { Masa kerja (tahun) } \\
\circ \leq 1 \\
\circ 1-5 \\
\circ 6-10 \\
\circ \geq 10\end{array}$ & $\begin{array}{l}2 \\
2 \\
3 \\
-\end{array}$ & $\begin{array}{c}28,57 \\
28,57 \\
42,86 \\
-\end{array}$ \\
\hline 5. & $\begin{array}{l}\text { Kepemilikan usaha } \\
\text { o Sendiri } \\
\text { o Bukan milik sendiri }\end{array}$ & $\begin{array}{l}7 \\
-\end{array}$ & $\begin{array}{c}100 \\
-\end{array}$ \\
\hline
\end{tabular}


Tabel 2. Hasil uji boraks dan formalin terhadap sampel jajanan

\begin{tabular}{ccccc}
\hline No. & Kode Sampel & Kandungan Boraks & $\begin{array}{c}\text { Kandungan } \\
\text { Formalin }\end{array}$ & Penjual Jajanan \\
\hline 1. & A & Negatif & Negatif & Sosis \\
2. & B & Negatif & Negatif & Sosis \\
3. & C & Negatif & Negatif & Sosis \\
4. & D & Negatif & Negatif & Tahu \\
5. & E & Negatif & - & Iteng \\
6. & F & Negatif & - & Sempol \\
7. & G & Negatif & - & Pempek \\
8. & H & Positif & - & Cireng \\
9. & I & Positif & - & Cilok \\
\hline
\end{tabular}

Tabel 3. Persentase sampel jajanan

\begin{tabular}{cccccccc}
\hline \multirow{2}{*}{ No. } & \multirow{2}{*}{ Kandungan Sampel } & \multicolumn{2}{c}{ Positif } & \multicolumn{2}{c}{ Negatif } & \multicolumn{2}{c}{ Jumlah } \\
& & $\mathrm{N}$ & $\%$ & $\mathrm{~N}$ & $\%$ & $\mathrm{n}$ & $\%$ \\
\hline 1. & Boraks & 2 & 22,22 & 7 & 77,78 & 9 & 100 \\
2. & Formalin & 0 & 0 & 4 & 100 & 4 & 100 \\
\hline
\end{tabular}

Hasil uji kandungan boraks dan formalin yang dilakukan secara kualitatif dengan menggunakan test kit terhadap 9 sampel jajanan yang ada disekitar Universitas Yudharta Pasuruan dapat dilihat pada Tabel 2 berikut ini.

Berdasarkan Tabel 2 diketahui bahwa dari 9 sampel jajanan yang diuji secara kualitaif dengan menggunakan test kit menunjukkan 2 sampel $(22,22 \%)$ positif mengandung boraks dan 7 sampel $(77,78 \%)$ negatif mengandung boraks. Hasil tersebut diperoleh setelah membandingkan warna kertas uji dengan warna kertas standar.

Pada uji formalin dari 4 sampel jajanan yang di uji secara kualitatif, tidak satu pun sampel yang terbukti mengandung formalin. Hal ini dilihat dari tidak adanya perubahan warna yang terjadi pada sampel jajanan yang diuji.

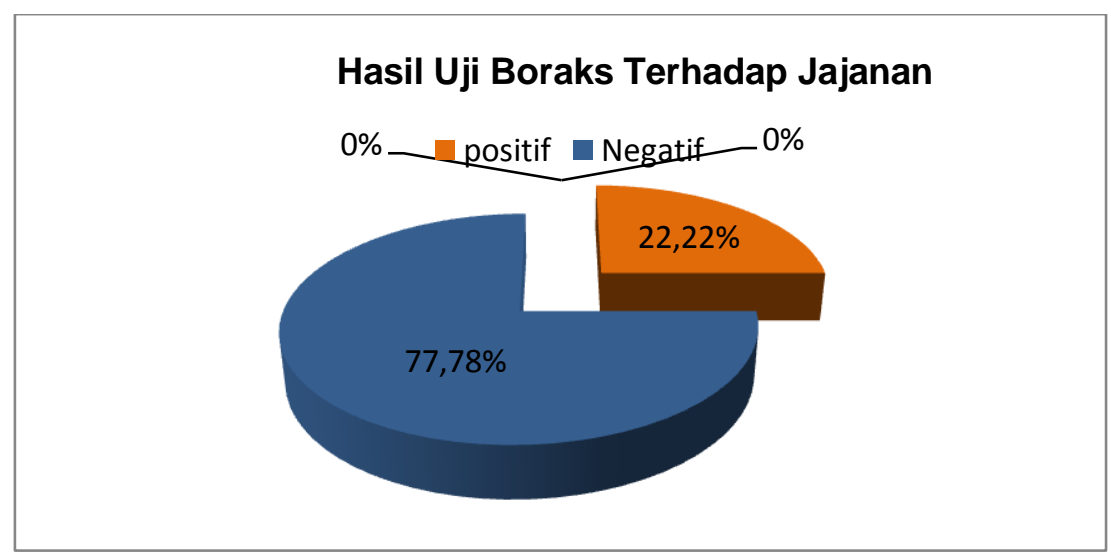

Gambar 2. Hasil uji boraks terhadap jajanan disekitar Universitas Yudharta Pasuruan 

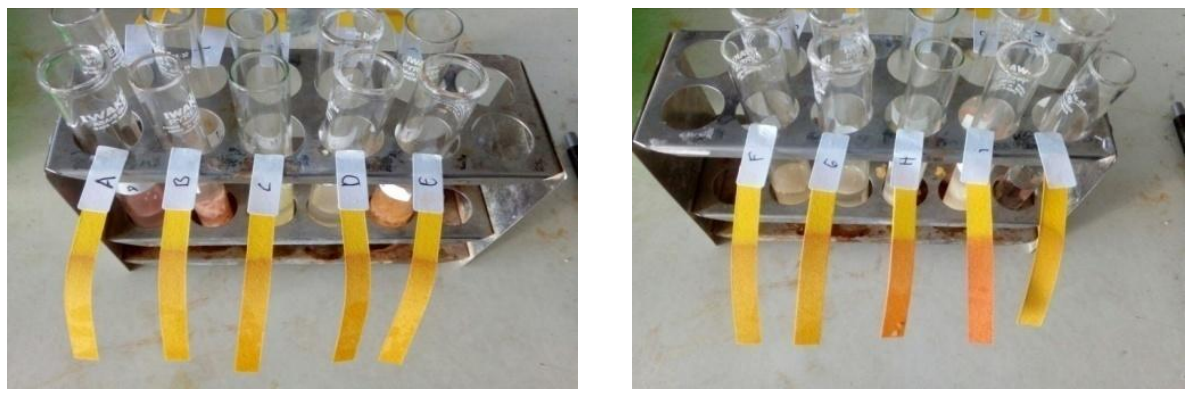

Gambar 3. Sampel hasil uji boraks

Hasil Uji Formalin Terhadap Jajanan

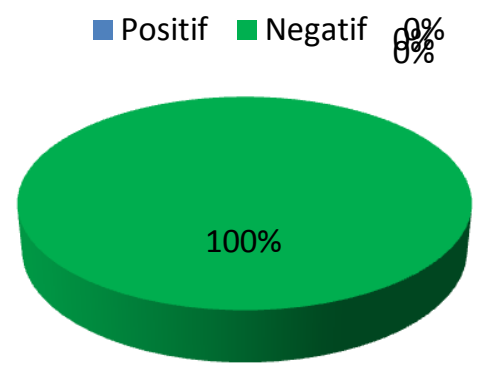

Gambar 4. Hasil uji formalin terhadap jajanan disekitar Universitas Yudharta Pasuruan

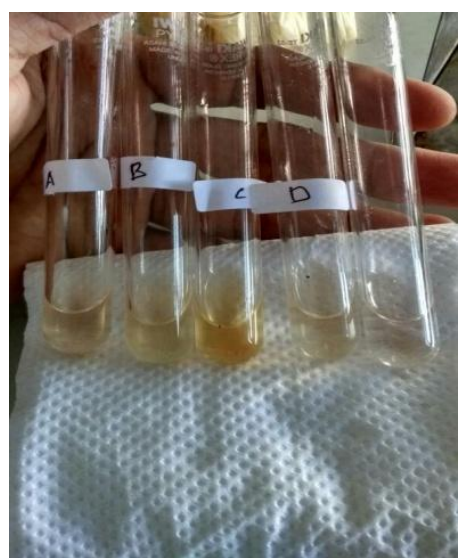

Gambar 5. Sampel hasil uji formalin

Dari 9 sampel jajanan yang diuji, 2 sampel positif mengandung boraks yaitu sampel $\mathrm{H}$ dan $\mathrm{I}$ dan 7 negatif mengandung boraks yaitu sampel A, B, C, D, E, F dan G yang telah disajikan dalam tabel 2. Hal tersebut dinyatakan positif karena adanya perubahan kertas lakmus yang berubah menjadi warna merah. Perubahan warna merah disebabkan karena pembentukan senyawa rososianin berwarna merah dari 
boron dan kurkumin dalam suasana asam. Senyawa rososianin inilah yang menjadi indikator ada tidaknya boraks dalam sampel jajanan yang diuji (Fauziah, 2014).

Sampel yang dinyatakan positif adalah sampel $H$ berupa cireng dan sampel I semacam cilok yang dibalut dengan telur. 2 sampel ini memiliki kesamaan yaitu terbuat dari tepung-tepungan yang dicampur dengan bumbu-bumbu lainnya. Hal ini bisa diduga menggunakan boraks (bleng) untuk mengenyalkan adonan agar teksturnya menjadi lebih enak saat dimakan.

Hal ini juga sama disampaikan oleh Fauziah (2014) dalam penelitiannya yang berjudul "Kajian keamanan pangan bakso dan cilok yang beredar di lingkungan Universitas Jember ditinjau dari kandungan boraks, formalin dan TPC". Hasil analisa menunjukkan bahwa dari 13 sampel cilok, 92\% diantaranya positif mengandung senyawa berbahaya boraks. Pada sampel bakso, dari 30 sampel yang dianalisa $17 \%$ diantaranya terdeteksi mengandung senyawa berbahaya boraks.

Boraks merupakan racun bagi semua sel. Pengaruhnya terhadap organ tubuh tergantung konsentrasi yang dicapai dalam organ tubuh. Kadar tertinggi tercapai pada waktu diekskresi maka ginjal merupakan organ yang paling terpengaruh dibandingkan dengan organ yang lain. Dosis fatal penggunaan boraks adalah 5-20 g/hari (Badan POM, 2002). Sedangkan menurut standar internasional dosis fatal boraks berkisar 3-6 g/hari untuk bayi dan anak kecil, untuk orang dewasa sebanyak 15-20 g/hari (Litovitz et al., 1998 dalam WHO, 1998).

Pada uji formalin dengan menggunakan test kit, menunjukkan bahwa tidak satu pun jajanan yang mengandung formalin dari 4 sampel yang diuji. Sampel tersebut diberi kode A, B, C dan D. Sampel-sampel tersebut antara lain : sampel A dan B berupa sosis, sampel $\mathrm{C}$ berupa sosis yang dililit mie basah dan sampel D berupa tahu. Sampel-sampel tersebut dinyatakan negatif dikarenakan tidak adanya perubahan warna menjadi pink keunguan.

Hal ini juga sama seperti yang dipaparkan dalam penelitian Fauziah (2014) pada sampel cilok dan bakso yang beradar di lingkungan Universitas Jember. Sampelsampel tersebut berjumlah 43 sampel yang terdiri dari 13 sampel cilok dan 30 sampel bakso. Berdasarkan hasil uji formalin pada sampel-sampel tersebut menunjukkan bahwa sampel cilok dan bakso tidak satupun menunjukkan hasil positif mengandung formalin.

Menurut hasil penelitian Maidah (2015) yang berjudul "Analisis kualitatif dan kuantitatif natrium benzoat, boraks dan formalin di lingkungan sekolah dasar kecamatan Tamalanrea kota Makassar" menunjukkan dari 10 sampel yang diuji yang terdiri dari donat SDN Tamalanrea IV, bakwan SDN Tamalanrea IV, donat SD Inpres unhas, siomay SD Inpres unhas, cimol SDN Bung, siomay SDN Bung, bakwan SDN Bung, kecap merk A, B dan C, tidak satupun sampel yang dinyatakan positif mengandung boraks dan formalin, namun 3 sampel dinyatakan positif mengandung natrium benzoat yaitu sampel kecap merk A, B dan C.

Hal ini berbeda dengan penelitian yang dilakukan Mudzkirah (2016) di kantin UIN Alauddin Makassar, menyatakan dari 12 sampel makanan jajanan yang diuji, 6 sampel positif mengandung formalin. Sampel-sampel tersebut antara lain : mie, tahu, bakso, mie goreng, mie pangsit dan tahu bakso. Dari 6 sampel yang dinyatakan positif, selanjutnya sampel akan diuji kadar formalinnya dengan mengguanakan metode spektrofotometer UVVIS. Dari hasil pemeriksaan, kadar formalin paling tinggi terdapat pada sampel mie dengan kadar $1,7140 \mathrm{mg} / \mathrm{L}$ dan yang paling rendah adalah sampel tahu dengan kadar $0,6631 \mathrm{mg} / \mathrm{L}$.

Formalin merupakan zat berbahaya bagi tubuh manusia. Uap formalin dapat 
menimbulkan iritasi mata dan hidung, serta gangguan saluran pernafasan. Hal ini disebabkan karena senyawa formalin cepat bereaksi dengan asam amino yang menyebabkan protein tubuh tidak dapat berfungsi. Dampak dari pemaparan ini formalin terakumulasi pada lapisan lendir saluran pernapasan dan saluran pencernaan. Formalin yang masuk ke tubuh manusia di bawah ambang batas akan diurai dalam waktu 1,5 menit menjadi $\mathrm{CO}_{2}$. Ambang batas yang aman adalah 1 miligram perliter (Harmoni, 2006).

\section{Ciri Makanan Mengandung Boraks dan Formalin}

Berikut merupakan ciri makanan jajanan yang mengandung boraks dan formalin menurut BPOM (2014) :

1) Makanan mengandung boraks

a. Bakso : Teksturnya kenyal, dengan warna cenderung sedikit putih dan rasanya sangat gurih.

b. Kerupuk : Teksturnya sangat renyah dan bisa menimbulkan rasa getir.

2) Makanan mengandung formalin

a. Tidak rusak sampai 3 hari pada suhu kamar $\left(25^{\circ} \mathrm{C}\right)$ dan bertahan lebih dari 15 hari pada suhu lemari es $\left(10^{\circ} \mathrm{C}\right)$.

b. Bau menyengat dari formalin.

c. Mie basah tidak lengket dan tidak mudah putus.

d. Tahu memiliki tekstur sedikit keras, kenyal namun padat.

e. Ikan berformalin : Warna insang merah tua tidak cemerlang, bukan merah segar, dan warna daging ikan putih bersih. Tidak rusak sampai 3 hari pada suhu kamar.

f. Ikan asin berformalin : Bersih cerah dan tidak berbau khas ikan asin. Tidak dihinggapi lalat di area berlalat, tidak rusak sampai lebih dari 1 bulan pada suhu $25^{\circ} \mathrm{C}$.

g. Bakso berformalin : Teksturnya sangat kenyal, tidak rusak sampai 2 hari pada suhu kamar. h. Ayam berformalin : Teksturnya kencang, tidak disukai lalat, tidak rusak sampai 2 hari pada suhu kamar.

Jajanan Disekitar Universitas Yudharta yang Mengandung Boraks dan Formalin

Dari penelitian dapat dilihat pada Tabel 2 yang menyatakan bahwa sampel yang positif mengandung boraks adalah sampel $\mathrm{H}$ berupa cireng dan I berupa cilok yang dibalut telur. Kedua sampel tersebut positif mengandung boraks. Hasil tersebut diperoleh setelah membandingkan warna kertas uji (kertas lakmus) dengan warna kertas uji standar.

Sedangkan pada uji formalin, tidak satu pun sampel yang terbukti mengandung formalin. Hal ini dilihat dari tidak adanya perubahan warna yang terjadi pada sampel jajanan yang diuji.

Sehingga sampel yang aman untuk dikonsumsi adalah sampel A dan B berupa sosis, sampel $\mathrm{C}$ berupa sosis yang dililit mie, sampel D berupa tahu, sampel E berupa iteng, sampel $F$ berupa sempol dan sampel $G$ berupa pempek. Sampel-samepl tersebut tidak terbukti mengandung boraks dan formalin.

\section{KESIMPULAN DAN SARAN}

\section{Kesimpulan}

Berdasarkan hasil penelitian yang telah dilakukan, maka dapat disimpulkan bahwa :

1. Sampel yang positif mengandung boraks adalah sampel $\mathrm{H}$ berupa cireng dan I berupa cilok yang dibalut telur. Hasil tersebut diperoleh setelah membandingkan warna kertas uji (kertas lakmus) dengan warna kertas uji standar.

2. Sampel terbukti tidak satu pun yang mengandung formalin. Hal ini dilihat dari tidak adanya perubahan warna yang terjadi pada sampel jajanan yang diuji.

3. Sampel yang positif mengandung boraks dan formalin tidak ditemukan. Yang ditemukan hanya sampel yang positif mengandung 
boraks saja yaitu sampel $\mathrm{H}$ berupa cireng dan I berupa cilok yang dibalut telur.

4. Jajanan yang aman dikonsumsi adalah sampel A dan B berupa sosis, sampel C berupa sosis yang dililit mie, sampel D berupa tahu, sampel E berupa iteng, sampel F berupa sempol dan sampel G berupa pempek. Sampe-sampel tersebut dinyatakan negatif mengandung boraks dan formalin.

\section{Saran}

1. Perlu dilakukan penelitian lanjutan pada sampel jajanan disekitar Universitas Yudharta Pasuruan, seperti pengujian saos yang digunakan pada jajanan dan melakukan pengujian boraks dan formalin menggunakan bahan alami (misal untuk boraks menggunakan kunyit (Fuad, 2014) dan formalin menggunakan sari kulit buah naga (Wardani dan Anggraini, 2015)).

2. Perlu dilakukan penelitian serupa secara kuantitatif untuk mengetahui kadar kandungan boraks dan formalin dalam jajanan. Dan juga bisa dilakukakan uji makanan lain seperti : TPC (total plate count), coliform, e.coli, pewarna makanan (rodhamin B dan methanyl yellow) dan pemanis jajanan.

\section{DAFTAR PUSTAKA}

Adinugroho, N. 2013. Pengaruh pemberian boraks dosis bertingkat terhadap perubahan gambar makroskopis dan mikroskopis hepar selama 28 hari. Karya tulis ilmiah fakultas kedokteran. Universitas Diponegoro Semarang.

Astawan, M. 2006. Mengenal formalin dan bahayanya. Jakarta : swadaya.

Badan Standarisasi Nasional. 1992. SNI 01-29871992, tentang syarat mutu mie basah. Jakarta : Badan Standarisasi Nasional.

Badan Standarisasi Nasional. 1995. SNI 01-38201995, tentang syarat mutu sosis daging. Jakarta : Badan Standarisasi Nasional.
Badan Standarisasi Nasional. 1998. SNI 01-31421998 dan SNI No. 0270-1990, tentang syarat mutu tahu. Jakarta : Badan Standarisasi Nasional.

BPOM RI. 2002. Informasi Pengamanan Bahan Brebahaya: Boraks (Borax). Direktorat Pengawasan Produk dan Bahan Berbahaya, Deputi Bidang Pengawasan Keamanan Pangan dan Bahan Berbahaya. Jakarta.

BPOM RI. Laporan Tahunan 2011. Jakarta : BPOM RI; 2012.

Ditjen POM. 1979. Farmakope Indonesia. Edisi Ketiga. Jakarta. Departemen Kesehatan RI. hal. 49, 427-428

FAO.1997. Street Foods (FAO Food and Nutrition Paper). Report of An FAO Technical Meeting On Street Foods. India-Roma.

Fauziah, R.R. 2014. Kajian keamanan pangan bakso dan cilok yang beredar di lingkungan Universitas Jember ditinjau dari kandungan boraks, formalin dan TPC. Skripsi fakultas teknologi pertanian. Universitas Jember. Vol. 8 No. 1.

Hearn W.L., Walls H.C., Introduction to postmortem toxicology.In Postmortem Toxicology of Abused Drug. Boca Raton (US): CRP 15: 24-32.

Litovitz, T. L., W. K. Schwartz, G. M. Oderda and B. F. Schmitz. 1998. Clinical manifertations of toxicity in a series of 784 borac acid ingestion. American Journal Emergency Medical ,. 209-215.

Maidah. 2015. Analisis kualitatif dan kuantitatif natrium benzoat, boraks dan formalin di lingkungan sekolah dasar kecamatan Tamalanrea kota Makassar. Skripsi fakultas matematika dan ilmu pengetahuan alam. Universitas Hasanuddin Makassar.

Paratmanitya, dkk. 2016. Kandungan bahan tambahan pangan berbahaya pada makanan jajanan anak sekolah dasar di kabupaten Bantul. Jurnal gizi dan dietetic. Vol. 4 No. 1.

Permenkes RI No. 033/Menkes//2012. Tentang bahan tambahan pangan. 
Permenkes RI No. 1168/MENKES/Per/X/1999. Tentang Bahan Tambahan Makanan. Jakarta.

Permenkes RI No. 222/Menkes/IX/1988. Tentang bahan tambahan pangan.

PP RI No. 28 tahun 2004. Tentang Keamanan, Mutu dan Gizi Pangan.
Widyaningsih T.D. dan Murtini E.S., 2006. Alternatif pengganti formalin pada produk pangan. Jakarta: Trubus agrisarana.

Winarno, F. G. Dan Rahayu, S.S., 1994. Bahan Tambahan untuk Makanan dan Kontaminan. Pustaka Harapan. Jakarta.

World Health Organization. 1998. Boron, Guidelines for Drinking Water Quality. United States Environmental Protection. Ohio. 